\title{
インダス川全流域を対象とした 2010 年パキスタン洪水の降雨流出氾濫解析 RAINFALL-RUNOFF-INUNDATION ANALYSIS OF PAKISTAN FLOOD 2010 FOR THE ENTIRE INDUS RIVER BASIN
}

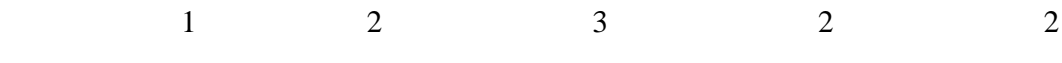 \\ Takahiro SAYAMA, Susumu FUJIOKA, Tomoki USHIYAMA, Yuuya TATEBE \\ and Kazuhiko FUKAMI \\ 1 正会員 博 (工) 土木研究所水災害・リスクマネジメント国際センター \\ ( ( 305-8516 茨城県つくば市南原 1-6) \\ 2 正会員工修 土木研究所水災害リスクマネジメント国際センター (同上) \\ 3 正会員 博 (理) 土木研究所水災害リスクマネジメント国際センター (同上)
}

\begin{abstract}
Pakistan suffered from a devastating flood disaster in 2010. This study investigated the potential of utilizing a rainfallrunoff-inundation (RRI) model for providing useful information for effective emergency response. The model was applied to the entire Indus River Basin (modeled area: 929,723 $\mathrm{km}^{2}$ ) with $60 \mathrm{sec}$. (about $1.7 \mathrm{~km}$ ) grid-cells, and its performance was evaluated based on the simulation results of river discharge and flood inundation. More specifically, a large-scale flood extending about $100 \mathrm{~km}$ apart from the main Indus River was focused for testing the model performance. Furthermore, by comparing different modelling settings including one- and two-dimensional kinematic and diffusive wave approximations and different treatments of embankment, the study discussed a suitable model structure to achieve the above objective with limited information. As a result, two-dimensional diffusive wave rainfallrunoff-inundation simulation without explicit considerations of embankment turned out to be the best combination for large-scale flood simulation for the case of the 2010 Pakistan flood.
\end{abstract}

Key Words: Indus River, Pakistan, flood, RRI Model, inundation, emergency response

\section{1.はじめに}

2010 年 7 月末から 9 月末にかけ, インダス川流域で 大規模な洪水が発生した . 2 力月にもおよゔ氵洪水期間 中には，兴の被災地域や形態がめまぐるしく変化した . 7 月末にはパキスタン北西部のカブール川流域で 1,100 名以上もの死者をもたらすフラッシュフラッドが発生 した .また，下流部のシンド州においては，サッカル 堰上流で堤防が決壊し, 本川から約 $100 \mathrm{~km}$ も離れた地 域にまで汇濫水が広がり, 多くの建物・農業・疫病被害 をもたらした .

こうした大規模洪水災害の際には, 政府は, 刻一刻 と変化する洪水の動向を俯瞰的に把握し, 住民避難の 指示や水工施設の管理を的確に行うことが大切である . 浸水域を特定する手段として, 近年, 衛星リモートセン シングの応用が進んでおり，UNOSAT などの国際機関 は, 災害直後からリモートセンシングの解析結果を配 信している．ただし, 衛星リモートセンシングにも撮 影頻度や空間解像度等の問題もあり，浸水域の拡大傾 向を時系列で把握したり，被害に直接関係する浸水深 を推定したりすることは難しい，弚こで，衛星リモー 卜センシングを補完する手段として，筆者らは水文モ
デルの応用に着目し, 全球任意の地域で迅速に水文モ デルを展開して, 河川流量から洪水氾濫までを一体的 に解析する手法の研究を進めている ${ }^{1,2)}$.

降雨流出と洪水氾濫とを一体的に解析できれば，従 来の分布型降雨流出モデルでは解析の難しかった低平 流域での河川流量の精度向上も期待できる.これまで の分布型流出モデルでは，地形の情報をもとに流れの 方向をあらかじめ決定し, 降雨から流出を計算してき た . 低平地を含む流域においては，流れの方向を地形 によって定めることが難しく，また洪水氾濫による河 川流量の変化を考慮できないため, 従来の分布型流出 モデルの適用性に問題があった . 流出と汇濫とを一体 的に解析することで, 氾濫の影響を考慮に入れた河川 流量の計算が可能となる .

広域を対象にした洪水氾濫解析は，これまでにもい くつかの研究事例がある.例えば, Kazama et al. ${ }^{3)} や$ Dutta et al. ${ }^{4)}$ はカンボジア周辺のメコン川流域を対象 に，乥れ光れ $15,400 \mathrm{~km}^{2}, 121,100 \mathrm{~km}^{2}$ の領域を $1 \mathrm{~km}$ のグリッドサイズで 2 次元氾濫計算を行っている . ま た , Yamazaki et al. ${ }^{5)}$ は, 約 $25 \mathrm{~km}$ グリッドサイズの全 球スケール水文モデルで 1 次元の流出計算を行いなが 
ら，兴のグリッドセル内部の貯留効果を反映させるこ とによって，大河川沿いの洪水氾濫を再現することを 実現している.さらに, Bates et al. $\left.{ }^{6}\right)$ は 2 次元拡散波近 似モデルとして LISFLOOD モデルを開発し，多くの適 用事例を報告している ${ }^{7)}$. 筆者らが開発を進める降雨 流出汇濫モデル (Rainfall-Runoff-Inundation Model: RRI Model $)^{1)}$ は, LISFLOOD モデルと同樣，拡散波近似を 適用した浅水方程式を有限体積法て離散化する。ただ し, 山地域の降雨流出現象を妥当に表現するため, 地 表流だけでなく地中流も同じ枠組みで表現する．さら に，山地域から平野部までの解析を安定かつ効率的に 解析するため, 数值解析法としては適応時間ステップ のルンゲクッタ法 ${ }^{8)}$ を採用している .

本論は，RRI モデルをインダス川全流域に適用し， 2010 年パキスタン洪水時の河川流量と洪水汇濫の再現 性を検証する，具体的には，カブール川に適用したモ デル構造とパラメータ ${ }^{1)}$ をインダス川全流域に展開し た際に，本川沿いの河川流量や下流部の広域洪水氾濫 をどの程度の精度で再現できるのかを検証する．また， 堤防の取り扱いなど計算条件の異なる 5 種類のモデリ ングを比較し，災害対応時の情報提供を目的としたモ デルとして，どのような構成が適するのかを論ずる．

\section{2. 降雨流出汇濫モデル}

RRI モデルは対象とする流域を斜面部と河道部とに 分けて取り扱う. 河道のあるグリッドセルにおいては， 一つのグリッドセルに河道と斜面の両方が存在する . 河 道はグリッドセルの中央を流れるべクトルとして表現 し，上・下流の接続情報を持つ. 降雨は斜面部にのみ

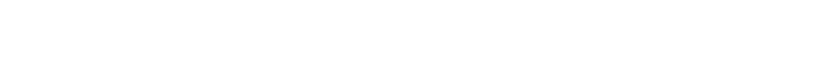
た後に，適当な時間刻みで斜面部と河道部との水のや り取りを計算する。

\section{（1）斜面部の 2 次元地中流・表面流モデル}

a) 浅水方程式

RRI モデルの斜面部には，2 次元の浅水方程式を拡散 波近似した式を用いる. 基礎となる 2 次元の浅水方程 式は以下のようである.なお,$x$ と $y$ 方向の運動量方程 式は類似するので, 以下では $x$ 方向のみを記載する .

$$
\begin{gathered}
\frac{\partial h}{\partial t}+\frac{\partial q_{x}}{\partial x}+\frac{\partial q_{y}}{\partial y}=r \\
\frac{\partial q_{x}}{\partial t}+\frac{\partial u q_{x}}{\partial x}+\frac{\partial v q_{x}}{\partial y}=-g h \frac{\partial H}{\partial x}-\frac{\tau_{x}}{\rho_{w}}
\end{gathered}
$$

ここに, $h$ は水深， $u, v$ は $x, y$ 方向の流速 $, q_{x}, q_{y}$ は $x, y$ 方向の流量フラックス $\left(q_{x}=u h, q_{y}=v h\right)$ である. また,$r$ は降雨強度, $g$ は重力加速度, $t$ は時間, $H$ は 基準面からの水位である . 右辺第二項は, Manning 則
を用いて次のように計算する .

$$
\frac{\tau_{x}}{\rho}=\frac{g n^{2} u \sqrt{u^{2}+v^{2}}}{h^{1 / 3}}
$$

ここに, $n$ は粗度係数である

b) 拡散波近似と空間的離散化

RRI モデルが仮定する拡散波近似は，(2) 式左辺の慣 性項を十分に小さいものとして無視する.さらに $x$ 方 向と $y$ 方向とを分けることによって，つまり，(3)中の $v$ の成分を無視することによって，以下のように書き換 える.

$$
q_{x}=-\frac{1}{n} h^{5 / 3} \sqrt{\left|\frac{\partial H}{\partial x}\right|} \operatorname{sgn}\left[\frac{\partial H}{\partial x}\right]
$$

ここに $\operatorname{sgn}$ は符号関数である. 例えば, 水位が $x$ 方向 に減る場合には, $\operatorname{sgn}[\partial H / \partial x]$ が-1 となるので, $q_{x}$ は正 の値となる.すなわち, $x$ 軸と同じ方向に水が流れるこ とを意味する．

(1) 式の連続式は,

$$
\frac{d h^{i, j}}{d t}+\frac{q_{x}^{i, j-1}-q_{x}^{i, j}}{\Delta x}+\frac{q_{y}^{i-1, j}-q_{y}^{i, j}}{\Delta y}=r^{i, j}
$$

のように空間的に離散化する ここに $, q_{x}^{i, j}, q_{y}^{i, j}$ は $(i, j)$ のグリッドセルから关れ光れ $x$ 方向, $y$ 方向に流出する 単位幅当たりの流量である. (4) 式にも同樣に空間差分 を適用することで各グリッドセルの水位からグリッド セル間の単位幅流量 $q_{x}$ を計算できる . 離散化した (4) 式を代入すると (5) 式は変数 $h$ の微分方程式となり, 以 下に示す解法で $h$ と $q$ の時間変化を追跡する .

c) 側方地中流

(4) 式は地表面流について流量と動水勾配との関係を 表した式である . RRI モデルは降雨流出と洪水氾濫と を一体的に解析することを念頭に置いているので, 地 表面流とあわせて支配的な地中流を簡単に再現するこ とが大切である . 地中の水の流れは, 斜面流下方向の 側方地中流が卓越する場合と，鉛直方向の浸透流が卓 越する場合とがある．RRI モデルでは，側方地中流に ついて , 山地流域で多くの適用実績がある中間流・表 面流を反映する流量流積関係式9)を用いる .

$$
q_{x}=\left\{\begin{array}{rr}
-k h \frac{\partial H}{\partial x}, \quad(h \leq d) & \\
-\frac{1}{n}(h-d)^{5 / 3} \sqrt{\left|\frac{\partial H}{\partial x}\right|} & \operatorname{sgn}\left[\frac{\partial H}{\partial x}\right] \\
-k(h-d) \frac{\partial H}{\partial x} & (d<h)
\end{array}\right.
$$

ここに $k$ は側方の飽和透水係数,$d$ は土層厚 $\times$ 有効空隙 率である.なお，もとの流量流積関係式は,キネマティッ クウェーブを仮定しており, 上式中の $\partial H / \partial x, \partial H / \partial y$ が 斜面勾配になっていることに注意する。

(2) 河道部の 1 次元拡散波近似モデル

河道部には 1 次元の拡散波近似モデルを適用する.河 道断面の主河道は長方形を仮定する。ただし，詳細な 
河道断面情報を得ることが出来ない場合には，第一次 近似として河道幅 $W[\mathrm{~m}]$ と深さ $D[\mathrm{~m}]$ を以下の式で算定 する ${ }^{10)}$.

$$
\begin{gathered}
W=C_{W} A^{S_{W}} \\
D=C_{D} A^{S_{D}}
\end{gathered}
$$

ここに $A\left[\mathrm{~km}^{2}\right]$ は当該河道区間の集水面積である .また， $C_{W}, S_{W}, C_{D}, S_{D}$ の河道パラメータは, 対象とする流 域毎に入手可能な断面情報から推定する.

(3) 斜面部と 河道部の水の流出入

河道が存在するグリッドセルにおいては, 計算の各 時間ステップで, 斜面セルと河道セルの水の流出入を 計算する. 兴の流出入量は, 河道の水位, 斜面の水位, 及び堤防高に応じて 4 つの場合分けを行い, 段落ち式・ 越流公式を用いて計算する。

\section{(4) 時間発展スキーム}

(5) 式で表される微分方程式を適応時間ステップルン ゲクッタ法で解く . 同法は, 通常のルンゲクッタ法で 微分方程式を解法すると同時に，光の誤差を推定する． RRI モデルは Cash and Karp ${ }^{8)}$ の提案した方法を採用し， 5 次の精度を有する 6 ステップルンゲクッタで次の時間 ステップにおける水深を推定するとともに , 4 次の精度 で計算した場合の水深を求めることによって両者の差 から計算誤差を推定する .

(5) インダス川適用のためのモデル拡張

a) 本川沿いの堤防について

インダス川の下流部においては, 本川から 5〜10 km 程度離れた場所に道路や盛土があり，氾濫水の拡大を 防ぐ堤防の役割を果たしている.本川沿いの堤防の影 響を簡単に流出氾濫計算にさせるため，以下の取り扱 いを行う．まず堤防のあるグリッドセルの標高を堤防 の高さに相当するように嵩上げする . 次に堤外地の粗 度は氾濫原を代表する值に設定し，弚こでは地中流や 鉛直浸透流を考慮しない．堤外地の主河道については， 式 (7)，(8)で川幅と深さを設定したうえで，河川の流 量を推定する際は，主河道を流れる流量に汇濫原を流 れる流量を加算する .

b) 平野部の鉛直浸透流について

今回の洪水で主たる出水起源となったカブール川流 域の山間部では, 過去の森林伐採と乾燥・半乾燥の気候 帯の影響によって, 植生で覆われた場所が少なく, 多く の場所で基岩が露呈している．基岩の地質は，変成岩 や堆積岩が主体であり, 光れらが風化作用を受けて薄 い土層を形成している ${ }^{11)}$. 急勾配の斜面上に形成され た土壤中では, 表層付近の早い地中流が発生し, 弚れ が飽和した場合に表面流が発生するものと想定される． 従って，山間部においては，薄い土層厚を設定した中 間流・表面流モデルの適用が妥当である．一方，イン ダス川流域の下流部には, 農地・市街地として利用さ

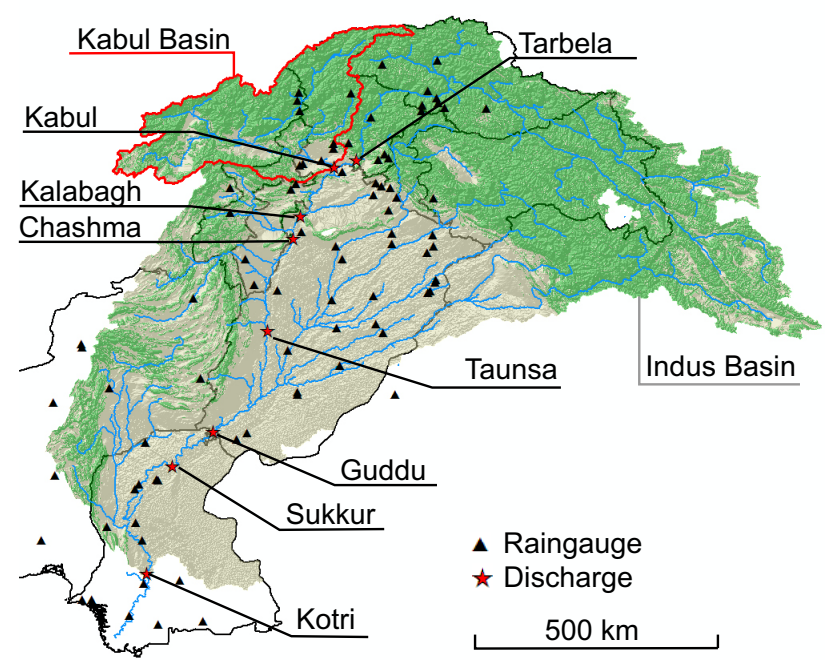

図-1 インダス川流域と主要地点の位置関係

れている平野部が広がっており，乥こでは Green Ampt モデルを適用して，鉛直浸透による損失量を計算する． なお, 本論では, Mack et al. ${ }^{11)}$ を参考に, 勾配 0.05 を 閾値として山地と平野部とに分けることにした .

\section{3. 計算条件}

本研究の対象領域は, Kotri 堰上流のインダス川全流 域 (面積 : 929,723 km²) とする . 図-1 中の星印 (Kabul 地点を除く)は, インダス川本川沿いにあるダム・堰の 位置を示す. 2010 年の洪水期間中は, Tarbela ダムで一 部洪水調節が行われたものの, 弚の効果は限定的であ り, 本研究の解析では洪水調節の効果を考慮しない. 河 川流量の再現性検証については, 各公ム・堰における 流入量の観測結果を用いる．また，Kabul地点は水位計 測に基づく流量推定値を比較対象とする.

本研究は HydroSHEDS に含まれる $30 \mathrm{sec}$ 地形データ セットを $60 \mathrm{sec}\left(\right.$ 約 $1.7 \mathrm{~km}$ ) に低分解能化して用いる ${ }^{12)}$. HydroSHEDS には標高·落水方向・集水面積を含み, 落 水方向と集水面積データは, 河道の接続関係と形状を 規定するために用いる . 河道の幅と深さは (7)，(8) 式 で算定し, 光のパラメータ $\left(C_{W}, S_{W}, C_{D}, S_{D}\right)$ は, イ ンダス川本川沿いの地形図・衛星画像を参考にしなが ら, 弚れ光れ 3.5, 0.4, 0.1, 0.4 とした . ただし, 河道深 さの上限值は $5 \mathrm{~m}$ とした .

表-1に今回の比較検討で用いた計算条件の一覧を， 表-2に使用したモデルパラメータの值を示す．RRI モ デルは, 上述の通り 2 次元の拡散波近似モデルを基本 構成としており, 光の条件を2D-Dif と呼ぶ .一方, 従 来の分布型流出モデルと比較するために, 地形勾配か らあらかじめ落水方向を決め, キネマティックウェーブ 法で追跡する場合を1D-Kin，1 次元拡散波近似で追跡 した場合を 1D-Dif と呼ぶ . 以上の3 ケースは本川も含 
表-1 計算条件

1D-Kin 1 次元 Kinematic Wave モデル

1D-Dif 1 次元 Diffusion Wave モデル

2D-Dif 2 次元 Diffusion Wave モデル

2D-Dif-Lev 2D-Dif + 堤防あり (破堤なし)

2D-Dif-LeB 2D-Dif + 堤防あり (破堤あり)

表-2 モデルパラメータ

\begin{tabular}{llll}
\hline & 山地 & 平野 & 堤外 \\
\hline$d(\mathrm{~m})$ & 0.1 & 0.0 & 0.0 \\
$k(\mathrm{~m} / \mathrm{s})$ & 0.1 & - & - \\
$n\left(\mathrm{~m}^{-1 / 3} \mathrm{~s}\right)$ & 0.15 & 0.15 & 0.15 \\
Green Ampt 土質 & - & Silty clay loam & - \\
$n$ [river] $\left(\mathrm{m}^{-1 / 3} \mathrm{~s}\right)$ & & 0.015 & \\
\hline
\end{tabular}

めて無堤を仮定する．弚れに対して，2D-Dif-Lev は本 川沿いに比高 $10 \mathrm{~m}$ の連続堤があることを想定した場合 とする . 2D-Dif-LeB は本川沿いに堤防があることを想 定したうえで， 2010 年の洪水で大きく破堤した場所に は堤防が無いことを想定した条件とする.

計算対象期間は 2010 年 7 月 20 日 0:00(UTC) から 9 月 20 日 0:00(UTC) までの 62 日間とする. 同期間の入力 降雨分布は, 図-1 に示す 93 地点で観測された日雨量を 最近隣法で空間内括て作成する.計算の初期条件は， 完全に乾燥した状態を想定する．なお，RRI モデルは OpenMPによる並列計算に対応しており，PC (Intel Xeon W3580, 3.33GHz, 4cores/8threds, RAM: 3.25GB) を用い た場合，62 日間の計算を約 10 時間で実行できる.

\section{4. 計算結果}

(1) 河川流量の再現性について

RRI モデルの適用結果を以下に示す. 図-2 は主要地 点の流量について, 計算流量と観測流量との比較を示 す . 本論では、2 次元拡散波近似による汇濫の再現が河 川流量に及ぼす影響を確認するため、2D-Dif の結果と 併せて、1D-Kin の結果を示す．

図中の Kabul 地点は, Sayama et al. ${ }^{1}$ で対象とした流 域であり，本論のモデルパラメータは，同地域の 7 月 下旬の出水を概ね再現できるように設定している．

インダス川中流部の本川に位置する Kalabagh 地点， Taunsa 地点, Chashma 地点, Guddu 地点の河川流量に 着目する .この4地点については, 計算・観測結果か概 ね同じような傾向を示しており，1D-Kin ではピーク流 量の出現が大きく・早くなり過ぎるのに対し，2D-Dif で汇濫を考慮しながら計算を行うことによって，観測 流量をよく再現できるようになる .これらの 4 地点の 計算流量の再現性を Nash 指標で評価すると，2D-Dif で は 0.56 となった . 後述する図-6にはこの 4 地点の Nash 指標の平均値を Nash(Mid) として示している.
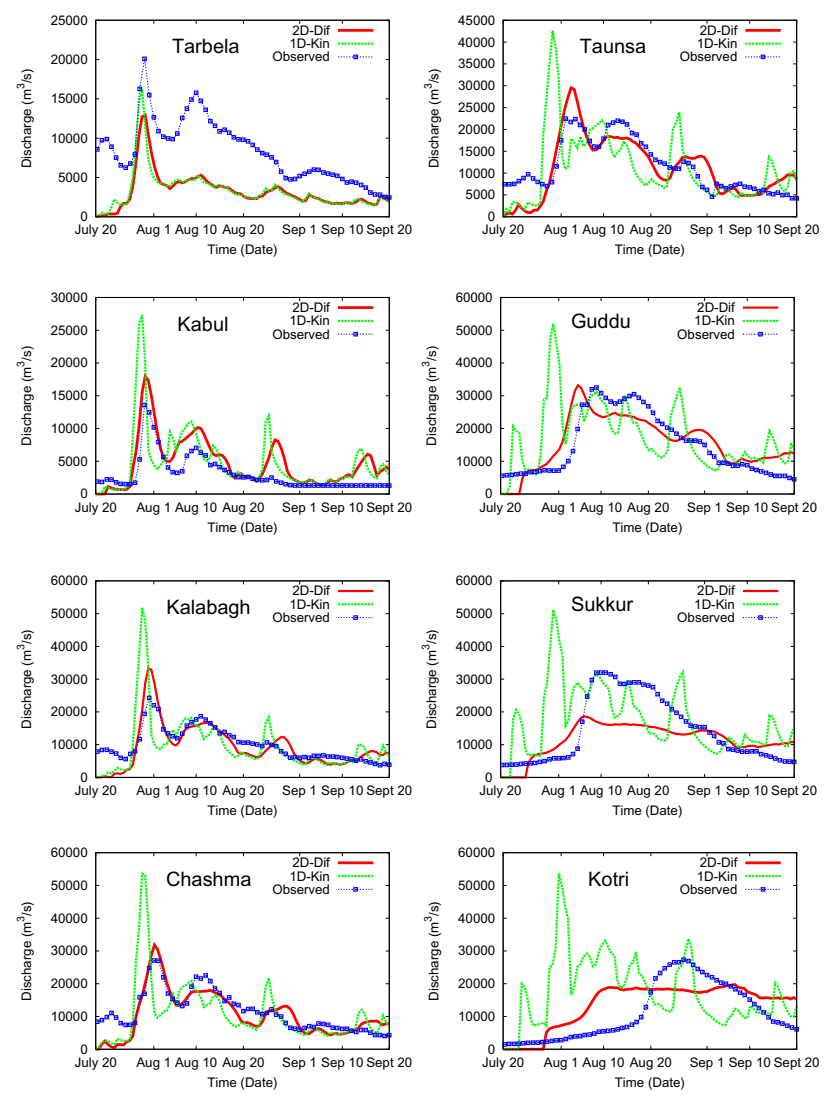

図-2 各地点の観測流量と計算流量との比較

表-3 流域水収支 (単位:mm) (斜面, 河道は残留量)

\begin{tabular}{rrrrrr}
\hline & 降雨 & 浸透 & 流出 & 斜面 & 河道 \\
\hline 1D-Kin & 267.8 & 143.7 & 106.3 & 11.5 & 6.3 \\
2D-Dif & 267.8 & 149.4 & 84.7 & 21.8 & 11.9 \\
\hline
\end{tabular}

インダス川下流部の Sukkur 地点・Kotri 地点に着目す る. 両地点は, 大規模な破堤地点の下流に位置してい る.2D-Dif の計算結果は, 観測流量を過小に評価して おり，本川から汇濫域への配分を妥当に再現できてい ない可能性がある.1D-Kin と比較しても2D-Dif の流 出量が小さくなるのは, 計算終了時点での斜面・河道 に残留している水の量が多いこと, また, 浸透の総量 が多いことによる (表-3) . この 2 地点の Nash 指標の平 均值 (Nash(Down)) は 2D-Dif で 0.40 となっており，中 流域の兴の值よりも低くなる．

本川の最上流に位置する Tarbela ダムについては, 1DKin，2D-Dif ともに計算結果か観測流入量を過小評価す る. Tarbela ダムの上流は, 標高 $6,000 \mathrm{~m}$ を超える山岳 地帯となっており, 地点雨量の情報がほとんど入手で きておらず，衛星観測降雨で補完している .

\section{（2）広域氾濫の再現性について}

図-3 は計算期間中の最大浸水深を示している . また， 中・下流域を拡大し, 最大浸水深とあわせて MODIS に よる浸水想定域を赤線で重ねて示している.なお，こ 


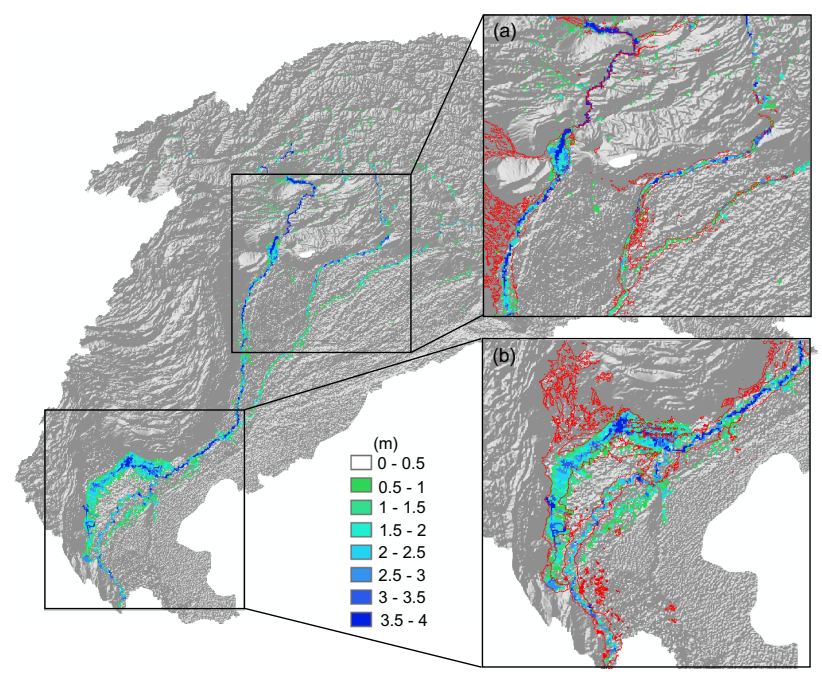

図-3 計算期間中の最大浸水深 (2D-Dif): (a) 中流域 (Mid) と (b) 下流域 (Down) の拡大図には MODIS による浸水域 (洪水期間中に一度でも浸水した地域) を赤線で重ねて 標記 .

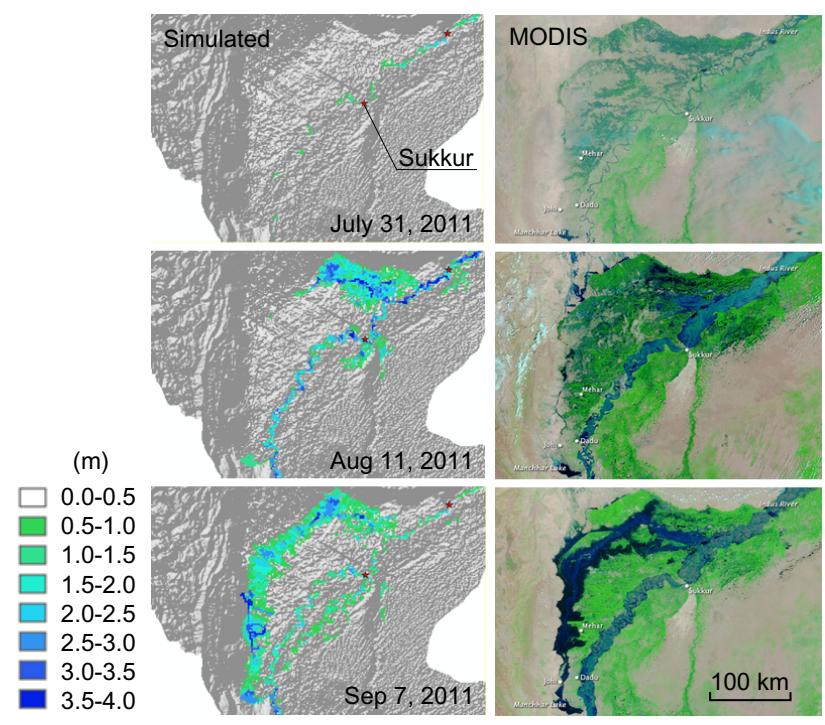

図-4 下流域における洪水氾濫: 2D-Dif による計算と MODIS 画像との比較 (MODIS 画像は青い部分が水域)

の浸水想定域は, 2010 年の洪水期間中に撮影された複 数の MODIS 画像をもとに , 同期間中に一度でも浸水 したと判断された地域である。

まず, 中流域では，拡大図の西側に位置する本川沿い に加えて , Jhelum と Chenab と呼ばれる支川沿いで浸 水したことをモデルは示している．この地域には，光 の南側にも主要なインダス川支川が位置しており，光 のうちの上記の二支川でとくに浸水域が広がっている ことを MODIS 分析結果からも確認できる.

本論では，氾濫域の再現性を示す定量化するために， 以下の $F I T$ 指標 ${ }^{7}$ を用いる.

$$
F I T=\frac{I A_{o b s} \cap I A_{\text {sim }}}{I A_{o b s} \cup I A_{\text {sim }}}
$$

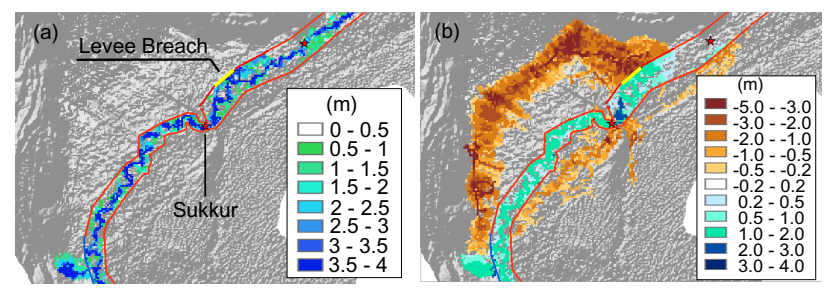

図-5 (a) 堤防が破堤しないことを仮定した場合 (2D-Dif-Lev) の下流域における最大浸水深, (b) 堤防ありの場合 (2DDif-Lev) と無堤の場合 (2D-Dif) の最大浸水深の差

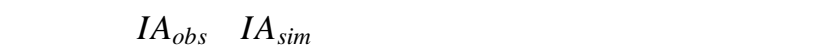
定された浸水域であり，この指標が 1 に近いほど両者 が整合したことを意味する．なお，IA $I A_{\text {sim }}$ については， 計算期間中の最大浸水深が $1 \mathrm{~m}$ を超えたグリッドセル について計上した . 図-3 中の右上に示した中流域 (Mid) で計算した FIT 指標は 0.30 となる。

次にインダス川下流域に着目する . 図-4 の時系列か らも分かるように, この地域では, 洪水が本川 (南東側) の右岸側から汇濫し, 本川から約 $100 \mathrm{~km}$ も西側に離れ て流れた . 実現象としては，堰の上流で堤防が一部決壊 して氾濫水が広がったとの報告がある . 2D-Dif の計算 は，堤防を考慮しない計算であるが，乥れでも概ね氾 濫水の挙動を再現できる .なお，詳細に見れば Sukkur 堰の左岸側などの一部地域では, MODIS によれば浸水 していないにもかかわらず，モデル結果は浸水してい る場所がある.これは破堤した場所を除く堤防の考慮 (2D-Dif-LeB) で改善する．ただし，FIT 指標で判断し た場合の再現性は光れほど顕著に改善されることはな く,2D-Dif の場合は 0.41 であるのに対し，2D-Dif-LeB の場合は 0.44 となる.

\section{(3) 堤防の効果について}

本川沿いの堤防か破堤しなかった場合を 2D-Dif-Lev としてシミュレーションとする. 図-5 の赤線で示した 場所は堤防の位置を示している.黄線で示した場所は 今回の洪水で堤防が決壊した場所である . 2D-Dif-Lev の計算では両者に堤防があることを，2D-Dif-LeB では 赤線の場所のみに堤防があることを想定して計算する . また，図中の青線の部分は，氾濫水が Manchar 湖に流 入してから本川に戻る場所であり，両条件ともこの部 分の堤防が無いものと仮定した .

2D-Dif-Lev による下流部の最大浸水深を図-5(a) に， 2D-Dif との最大浸水深の差を図-5(b) に示す . 図-5(b) の 値が負の場合は，堤防によって浸水深が低減したこと を，正の場合は堤防によって逆に水位が上昇したこと を示唆する.2D-Dif-Lev の条件では, 本川から堤内地 に水が溢机出ることはなくなり，堤内地はほとんど浸 水していない，一方，河川や氾濫原の水位は約 $2 \mathrm{~m}$ 上昇 しており，堤防が決壊しなければ周辺市街域の洪水リ スクが高まる．また堰のある地点では堤防の区間が狭 


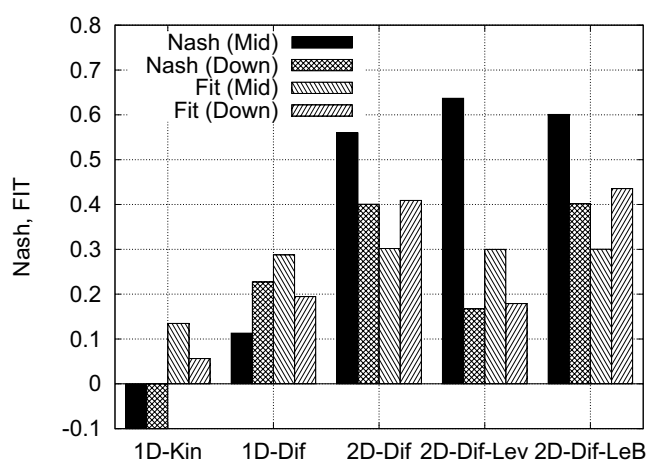

図-6 中流域 (Mid), 下流域 (Down) における河川流量 (Nash) • 洪水氾濫 $(F I T)$ の評価指標値

くなっており, 弚の影響で破堤地点周辺の水位が上昇 していることを計算結果は示唆している.

\section{(4) モデルの複雑性と再現性について}

全ての条件による計算結果を図-6にまとめる . 中流 域 (Mid) と下流域 (Down) について , 河川流量を Nash 指標, 洪水氾濫を FIT 指標で評価する . 2D-Dif の結果 を基準に考えると，1D-Kin は流出・氾濫ともに再現性 が悪い . 1D-Dif は河川流量を過大評価するが，钅の波 形は 2D-Dif に類似している (図は省略)．1D-Dif の氾濫 計算結果は, 中流域の河川沿いの氾濫を概ね再現でき るのに対し，下流域の大規模な氾濫は 1 次元計算では 全く再現できない .

堤防の考慮については，破堤の影響を反映させない 場合 (2D-Dif-Lev) は，無堤の場合 (2D-Dif) よりも下流 域の流量・氾濫の再現性が大幅に低下する．破堤地点 だけ堤防を付けない 2D-Dif-LeB は下流部の汇濫計算の 結果が 2D-Dif に比べて向上するものの，FIT 值で評価 した場合には，兴の効果は限定的である $(0.41$ から 0.44 に向上). 従って，破堤の情報などが十分に得られない 状況下では, まずは無堤を仮定した 2 次元の降雨流出 氾濫計算を実行することが, 災害対応のための情報提 供のためには有効であると考えられる．

\section{5. おわりに}

本研究は, インダス川全流域を対象に，降雨流出氾 濫モデルを適用し，2010 年パキスタン洪水の再現性を 検証した . モデルの計算結果は, 中流域の河川流量 , 下 流部の大規模洪水汇濫を概ね再現できた．堤防の取り 扱いなど計算条件の異なる 5 種類のモデリングによる 結果から，災害対応時の情報提供を目的としたモデリ ングとして，まずは無堤を仮定した 2 次元の降雨流出 氾濫解析が望ましいことが分かった . また , 同モデル による解析は, 洪水氾濫リスクの高い地域を特定した り，堤防等の影響を定量評価したりするうえで有効な 方法となり得ることが分かった．
本論のモデル適用においては, 支川のカブール川で 使用したモデルパラメータ ${ }^{1)}$ を直接利用した . カブー ル川の適用では計算負荷が比較的小さいため，簡単な パラメータ感度分析を実施することができた .一方，今 回の適用では, 計算負荷が大きく結果の不確実性を定 量化できていない，今後，観測情報を十分に得られな い地域にモデルを適用していくうえで，パラメータの 設定方法と光れに伴う不確実性を明らかにすることが 大切である .

謝辞: 科学研究費補助金若手研究 (B) 22760379 (代 表：佐山敬洋)の補助を受けた. 記して謝意を表する.

\section{参考文献}

1) Sayama, T., Ozawa, G., Kawakami, T., Nabesaka, S. and Fukami, K.: Rainfall-runoff-inundation analysis of Pakistan Flood 2010 at the Kabul River Basin, Hydrol. Sci. J., 2011, (in print).

2) 佐山敬洋, Lin, N.M., 深見和彦, 田中茂信, 竹内邦良: 降 雨流出氾濫モデルによるサイクロンナルギス高潮氾濫シ ミュレーション, 水工学論文集, 55, S529-534, 2011.

3) Kazama, S., Kono, T., Kakiuchi, K. and Sawamoto, M.: Evaluation of flood control and inundation conservation in Cambodia using flood and economic growth models, $\mathrm{Hy}$ drol. Process., 23(4), pp. 623-632, 2009.

4) Dutta, D., Alam, J., Umeda, K., Hayashi, M. and Hironaka, S.: A two-dimensional hydrodynamic model for flood inundation simulation: a case study in the lower Mekong river basin, Hydrol. Process., 21, pp. 1223-1237, 2007.

5) Yamazaki, D., Kanae, S., Kim, H. and Oki, T.: A physically based description of floodplain inundation dynamics in a global river routing model, Water Resour. Res., 47, W04501, 2011.

6) Bates, P.D. and De Roo, A.P.J.: A simple raster-based model for flood inundation simulation. J. of Hydrol., 236, pp. 5477, 2000.

7) Hunter, N.M., Bates, P.D., Horritt, M.S. and Wilson, M.D.: Simple spatially-distributed models for predicting flood inundation: A review. Geomorphology, 90, pp. 208-225, 2007.

8) Cash, J.R. and Karp, A.H.: A variable order Runge-Kutta method for initial value problems with rapidly varying righthand sides, ACM Trans. on Math. Software, 16(3), 201-222, 1990.

9) Takasao, T. and Shiiba, M.: Incorporation of the effect of concentration of flow into the kinematic wave equations and its applications to runoff system lumping, J. of Hydrol., 102, pp. 301-322, 1988.

10) Carpenter, T.M., Sperfslage, J.A., Georgakakos, K.P., Sweeney, T. and Fread D.L.: National threshold runoff estimation utilizing GIS in support of operational flash flood warning systems, J. of Hydrol., 224, pp. 21-44, 1999.

11) Mack, T.J. et al.: Conceptual model of water resources in the Kabul Basin, Afghanistan. USGS Afghanistan, 168, Scientific Investigations Report, 2009-5262, 2009.

12）多谷敬一, 赤井計之, 馬籠 純: 格子状擬河道網のスケール 変換に関する新しい方法, 水文・水資源学会誌, 19(2), pp. 139-150, 2006. 